\title{
CLIOMETRICS IN SOUTH AFRICA ${ }^{1}$
}

\section{J. Fourie*}

\section{Abstract}

frican economic history is experiencing a renaissance, and South African economic history likewise. Combining newly transcribed large historical datasets with econometric techniques now standard in the economics literature, economic historians have greatly improved our understanding of South Africa's development over the centuries. Yet many questions remain. This paper reviews the most recent contributions, several of which are published in this special issue, and surveys the road ahead.

\section{Introduction}

Cliometrics, sometimes called econometric history, uses statistical analysis of largescale numerical data to test historical hypotheses. Until only a few years ago, this field of research was unknown in South Africa. Emerging in US economics departments in the 1960s (Greif, 1997), cliometrics took off in the 2000s owing to two related technologies: cheap computing power and software packages to analyse large datasets, and the large-scale digitalisation and transcription of historical data. Interest in the field has been driven not only by supply-side factors, though, but also by demand from researchers. Economists have realised that 'history matters' for explaining economic growth and comparing levels and trajectories of economic development. After at least two decades of the 'cultural turn' in history, influenced by postmodernist ideas that pushed against a positivist epistemology, historians have rediscovered the value of transcribing large numbers of historical documents and analysing them statistically (Hopkins, 2009). This is nowhere more apparent than in Africa, where economic history is experiencing a 'renaissance' (Austin \& Broadberry, 2014) and a 'data revolution' (Fourie, 2016).

\footnotetext{
${ }^{1}$ I would like to thank Willem H. Boshoff, Sophia du Plessis, Bokang Mpeta, Dieter von Fintel, the students of the 2018 postgraduate History class and seminar participants at the Stellenbosch Forum (28 June 2018) for comments on an earlier version of this paper. I apologise for any remaining errors of omission. The research reported here would not have been possible without support from the Department of Economics, the Faculty of Economic and Management Science's Elite Fund, and the National Research Foundation.

*LEAP, Department of Economics, Stellenbosch University. Email: johanf@ sun.ac.za
} 
In South Africa the use of descriptive statistics was commonplace in economic history research during the twentieth century (De Kock, 1924; De Kiewiet, 1941; Worden, 1985; Van Duin \& Ross, 1987; Shell, 1994), but the past decade has seen a pronounced increase in the number of papers that use statistical and econometric tools to investigate South African economic history questions (Fourie \& Schirmer, 2012). This paper reviews some of this recent literature, presents five new contributions published in this special issue of Studies in Economics and Econometrics, and discusses the way forward. The five papers present not only the latest methods used by South African cliometricians but also the diverse research topics they investigate.

\section{The precolonial period}

The precolonial period is the part of South African economic history we understand least well. While archaeological evidence and oral histories offer some insights, the lack of written numeric information prevents us from analysing wages or prices systematically in order to measure the living standards of people who lived in South Africa before European settlers arrived.

This has not prevented economic historians from exploiting the sources that are available. Delius and Schirmer (2014) use archaeological evidence from the area called Bokoni, a settlement that between 1500 and 1820 intensively farmed terraced fields stretching 150 kilometres along the eastern escarpment of Mpumalanga, the largest known terraced site in Africa. The authors argue that the Bokoni people formed part of a 'decentralised cooperative regional order' that was built around the logic of production and then replaced in the early nineteenth century by 'a new order built around the logic of extraction and war' which 'militated against the development of decentralised intensive farming and emphasised instead the accumulation of military technology most notably guns and the construction of military strongholds' (Delius \& Schirmer, 2014, p.37).

The lack of wage and price information available during this period has forced economic historians and other social scientists to be more creative. A growing body of evidence has combined archival and oral sources with climatic and environmental information (Nash \& Endfield, 2002; Klein et al., 2018), such as tree rings and ships' logs (Hannaford, Jones \& Bigg, 2015; Hannaford \& Nash, 2016). Klein et al. (2018) show how changing rainfall patterns can influence migration patterns and cause conflict, a notable example being the "wars of calamity' in Southern Africa (or mfecane) that followed when a volcanic eruption in Indonesia in 1815 caused climate changes. 
But often the first-order challenge is to enumerate precolonial populations. To count the Khoesan, ${ }^{2}$ Fourie and Green (2015) combine the opgaafrolle, the eighteenth and nineteenth-century tax censuses of settler households with diary entries of settler farmers connected to the colonial economy. In this issue, La Croix incorporates new archival information to revise their estimates.

\section{European settlement}

The arrival and settlement of European immigrants at the southern tip of Africa had a profound effect on the trajectory of economic development. The motley crew of European men who arrived in April 1652 to establish a refreshment station had no intention of colonising a territory; their purpose, as dictated by the Dutch East India Company, was to build, as cheaply as possible, a fort in Table Bay to supply food and fuel to ships rounding the Cape of Good Hope. Vegetables were to be grown in a garden around the fort and meat was to be obtained by trading with the local indigenous groups that inhabited most of what later would become the Cape Province. Of course, things were not that simple. The commander of the Cape station soon had to release Company servants to become farmers, beginning a process of gradual colonisation that would ultimately lead to the disintegration of Khoesan society, the arrival of thousands of Indian Ocean slaves and the high levels of inequality that characterise modern-day South Africa.

This history is familiar, but recent cliometric investigations into the nature of this small but consequential settler society have made some surprising discoveries. While historians have typically considered the eighteenth-century Cape to be an 'economic and social backwater', recent investigations, using information on wages and assets, show that the average Cape settler lived far above the subsistence level (Du Plessis \& Du Plessis, 2012; Fourie, 2013b). This is because, as first suggested by Robert Ross three decades ago, the Cape economy was more dynamic than earlier accounts would suggest (Van Duin \& Ross, 1987). As Boshoff and Fourie show $(2008 ; 2010)$, Cape farmers responded to the demand from the increasingly frequent and longer-staying ships. The more than 6,000 sailors and soldiers who visited Cape Town each year during the eighteenth century provided a market for wheat, meat and, in particular, Cape wine. But it is the supply side that ultimately explains the settlers' high living standards: their access to inexpensive land (once the pastoral Khoe had been either pushed to the colonial frontier or drawn into the colonial economy), their use of slave labour, and the skills and institutions they had brought from Europe. Fourie and Von Fintel (2014) show that Huguenots from wine-making regions in France were more productive than those

\footnotetext{
${ }^{2}$ A collective term for the pastoral Khoe and hunter-gatherer San who inhabited the south-western region of southern Africa when Europeans arrived.

${ }^{3}$ See Trapido (1990, p.78).
} 
from wheat-producing regions. Fourie and Swanepoel (2018) show that networks of debt were deeply embedded in Cape society and used mostly for investment rather than consumption.

The European population at the Cape was initially augmented by migration, but high fertility rates soon took over and became the main reason for the territorial expansion. Using genealogical data, Cilliers and Mariotti (2017) plot these rates for the first time over the entire eighteenth and nineteenth centuries. While the average settler was relatively affluent, at least by the standards of the day, the averages mask high levels of inequality, even within settler society (Fourie \& Von Fintel, 2010; Fourie \& Von Fintel, 2011).

Much of the inequality in Cape society, though, was a consequence of the slave trade. The Cape economy depended on slave labour brought in from the Indian Ocean regions of modern-day Malaysia, Indonesia, India and Mozambique. Historians of the 1980s and 1990s had already begun to analyse the wealth of documents recording slave transactions, yet these contributions were mostly descriptive, focusing on estimates of population size and productivity (Worden, 1985; Shell, 1994). More recent contributions have used rigorous econometric approaches to understand the causes and consequences of slavery at the Cape. Baten and Fourie (2015) use the ages listed in court records to calculate numeracy levels and trends for Khoesan and imported slaves from Africa and Asia. Du Plessis, Jansen and Von Fintel (2015) use hedonic slave price indices and the value of the marginal productivity of slave labour to construct annual returns to investments in slave labour. They find that large-scale farmers enjoyed high returns to slavery over most of the period, while small-scale farmers did not recoup the costs of their slaves from agricultural production alone. This suggests that the small-scale farmers were either overinvesting in slavery (perhaps for status reasons) or using slave labour profitably outside of agriculture. Fourie (2013a) uses probate inventories to provide evidence for the 'economies of scope' that investments in slave labour offered.

Land was, of course, as important as labour for this pre-industrial society. Analysing the relationship between household composition and land availability in the GraaffReinet district from 1800 to 1828 , Cilliers and Green (2017) show that the number of children present in farming households increased with frontier closure, while the presence of non-family labourers decreased over time. The demand for family labour, they argue, was not a function of its marginal productivity. Poor households responded to shrinking land availability by employing relatively more family labour, while the wealthiest group opted for capital intensification instead.

In this issue, Swanepoel and Fourie add another factor to help explain the dynamism of the Cape economy. Using an instrumental-variable approach, they 
show that property rights mattered: despite the de jure loan farm property rights of the interior being weak, loan farms were as secure in their de facto property rights as freehold farms. This finding confirms that the local context in which property right regimes are embedded is at least as important as the property right regime itself.

\section{The mineral revolution}

The discovery of diamonds in the 1860s and gold two decades later transformed the South African economy. As migrants flocked to the interior, new towns like Kimberley and Johannesburg sprang up almost overnight, increasing the demand not only for labour and capital to work the mines but also for produce and other consumables to sustain the accelerating population. Greyling and Verhoef (2015) calculate GDP growth estimates for the Cape Colony, and find that GDP per capita grew $4.9 \%$ annually, while annual population growth was on average 3.9\%. This was faster than the GDP per capita growth of other settler colonies like Australia and New Zealand (Magee, Greyling \& Verhoef, 2016). What characterised this period, however, was 'the high volatility in the Cape Colony GDP throughout this period' (Greyling \& Verhoef, 2015, p.36).

Much of this growth was a consequence of new technologies that improved transport and communications. Herranz-Loncán and Fourie (2018) calculate that the impact of connecting Cape Town to the new mining towns of the interior explains almost half of the growth observed during the last three decades of the nineteenth century. Railroads connected Cape farmers and international markets to the interior demand, devastating the Basutoland economy, but integrating South Africa into the global market (Boshoff \& Fourie, 2017).

Gwaindepi (2018, p.ii-iii) uses the colonial blue books to show that income from the state-owned railway system was the second most important revenue item and combined with customs revenue formed the backbone of the Cape Colony's fiscal capacity development. He notes, however, that in its last days the Colony found itself 'in dire circumstances with high public debt and diminishing revenues' because of increasing rivalry with neighbouring colonies, like Natal, that captured the Cape's customs revenues and railway earnings. And, furthermore, the 'expenditure side was dominated by the elite-driven railway construction that primarily served the mining interests at the expense of all other sectors'. This meant that 'businessmen with mining interests steered the government towards policies or actions beneficial to their interests through legislation that prevented direct taxation on them'. 
Owing to poor record-keeping, we know much less about the livelihoods of the Boer Republics - the Orange Free State and the South African Republic. Du Plessis and Du Plessis (2017) take a novel approach to identify differences between the two Boer Republics. They use a statistical technique, Procrustes analysis, to gauge the accuracy of map boundaries in both republics as a proxy for institutional culture. They find evidence that, owing to its poor institutional quality, the South African Republic suffered a conditional resource curse after the discovery of gold.

Colonial mining and political interests clashed over the sovereignty of the Boer republics and contributed, ultimately, to the outbreak of the Second Anglo-Boer War in 1899, the largest and most expensive colonial war ever fought in the British Empire. Fourie, Grundlingh and Mariotti (2017) use attestation forms of the South African Constabulary, a volunteer force of recruits born in various parts of the British Empire. These forms, containing the personal information of 10,399 recruits, made it possible to assess and compare living standards in the latenineteenth century British territories.

Despite the annexation of the Boer Republic capitals of Bloemfontein and Pretoria within the first year, the Boer guerrilla tactics prolonged the war for another two years. This had deadly consequences, notably in the temporary concentration camps, built to house the non-combatants fleeing Lord Kitchener's scorched-earth policies. Du Plessis and Fourie (2016) use Elizabeth van Heyningen's transcribed lists of concentration camp inmates and survival analysis methods to investigate the length of stay and chances of survival in the camps. They calculate that the average stay in the camps was 278 days and that $23 \%$ of the inmates died. Their survival analysis shows that inmates from the Cape Colony remained in the camps longest. Although more women died in the camps, the probability that an individual would die after joining a camp was almost equal for men and women.

The end of the war brought the four territories into the Union of South Africa in 1910. The mineral revolution had vastly transformed the interior of South Africa. Ramela (2018) uses census documents to plot the evolution of the occupational structure of the Cape Colony between 1875 and 1909, and for South Africa as a whole between 1911 and 1953. He shows, using the PST classification system, how the mineral revolution shifted occupations for white South Africans from the primary to the secondary and tertiary sectors and pushed black workers into the primary sector, resulting in large racial cleavages in the workforce. Cilliers and Fourie (2018) also use occupations, obtained from genealogical records, to investigate occupational mobility for white males during the mineral revolution. Consistent with Ramela's (2018) evidence of a shift away from agriculture as the economy's dominant sector, they find increasing mobility for white males after the discovery of minerals in 1867 . They find upward mobility for semi-skilled white male workers, 'but virtually no improved mobility for sons of farmers' (Cilliers \& 
Fourie, 2018, p.3). Higher mobility for white males, they suggest, may have been a consequence of downward mobility for black males.

\section{$5 \quad$ Segregation and apartheid}

Twentieth-century South Africa exacerbated these racial disparities. Repressive and discriminatory legislation, such as the Colour Bar (job reservation) and the Land Act, protected the interests of the voter majority, mostly white men. ${ }^{4}$ The National Party, elected in 1948, introduced further policies that intervened in almost all aspects of society and continued until the 1980s, when the process of reform began that led to the 1994 democratic elections in South Africa.

Several studies provide an overview of the macro-economy during the twentieth century (Fedderke \& Simkins, 2012; Du Plessis \& Kotzé, 2010) or general poverty and inequality trends (Nattrass \& Seekings, 2011; Van der Berg, 2011), but because we lack consistent series on earnings or wealth for black South Africans, we have only limited understanding of the rise and fall of black living standards over that time. Mpeta, Fourie and Inwood (2018) address this by using four sources that contain records of heights: information available in the attestations of Second World War recruits, a dataset on cadavers, the Demographic and Health Survey, and the National Income Dynamics Survey. Height, or average stature of a population, is widely used as a proxy for living standards (Steckel, 1995). Combining the four sources reveals the change in heights of black males over the twentieth century: a decline during the first three decades, which the authors attribute to disease, war and land expropriation, followed by a sharp increase during the 1930s, probably as a result of expanded employment opportunities in mining, then after 1948 a slow increase. They also compare the heights of black and white males from the same sources, showing the persistently high levels of inequality between the two groups.

Information on heights can also reveal the causal effects of short-term shocks. Mariotti (2015) uses the unexpected increase in employment in 1975, 1976 and 1977 in the South African black 'homelands' or 'Bantustans' to compare the longterm adult outcomes of children whose fathers benefited from the employment increase with those whose fathers did not. Using a standard difference-in-difference approach, she finds 'that the (income) shock affected males who were either newborn or in utero at the time, providing support for the foetal-origins hypothesis and showing the importance of mother's nutrition' (Mariotti, 2015, p.485).

\footnotetext{
${ }^{4}$ White women only received the franchise in 1930 , and coloured voters were finally removed from the voters' roll in the Cape Province in 1951.
} 
The theoretical reasons for the emergence and decline of apartheid was a topic of much discussion in the 1980s and 1990s. ${ }^{5}$ More recent contributions have tended towards the empirical, relying on newly transcribed surveys and censuses. Mariotti (2012b) investigates, for example, the apartheid-era labour market. She shows that skill acquisition by white workers reduced the supply of semi-skilled workers throughout the apartheid era, and that this ultimately led to the removal of job reservation. She also shows that the elasticity of substitution between white and black production workers remained fairly high despite changes in the technology used in manufacturing, despite changes in the allocation of jobs to black and white workers, and despite the increasing differences in skills between white and black workers (Mariotti, 2012a). This suggests that 'African and white workers were substitutes throughout apartheid notwithstanding legislation restricting the types of jobs that African workers could do' (Mariotti, 2012a, p.47).

Nattrass (2014) calculates industrial profitability between 1960 and 1989. She finds that 'Marxist claims about cheap labour being the basis for supposedly rising profitability and growth under apartheid are not supported by the data'. Instead, she finds a decline in profitability and attributes it to falling capital productivity - which suggests that 'investment in the late apartheid period was misdirected in significant ways' (Nattrass, 2014, p.245). In this issue, Rönnbäck and Broberg calculate the return on British investments in South Africa during the period 1869 to 1969 and find it was substantially lower than what some previous research in the field has claimed.

Apartheid-era legislation affected not only the labour market but almost every aspect of South Africans' lives, including education (Eriksson, 2014; Giliomee, 2009), fertility decisions (Norling, 2018; Burger, Burger \& Rossouw, 2012), and migration. Abel (2015) shows how apartheid-era forced removals still affect South Africans' attitudes today. In this issue, Dieter von Fintel questions why spatial inequality persists in South Africa, with the former Bantustans being notably poorer, despite the removal of apartheid-era barriers to migration. Apartheid also isolated South Africa from the rest of the world, yet new trade and migration networks were nevertheless created. Also in this issue, Edward Kerby examines the links between trade flows and Taiwanese migration to South Africa from 1975 to 1995. He finds that the share of South African exports to Taiwan was both greater and more diversified in the sectors in which Taiwanese immigrants invested. Already before the end of apartheid, strong business and supply chain networks had been formed between South Africa and Asian markets.

${ }^{5}$ See Mariotti and Fourie (2014) for a detailed review. 


\section{Conclusions}

Historical statistics, often used for purposes orthogonal to the original reason for their collection, can help to offset the colonial biases of some qualitative sources, including those from South Africa, where history writing was often the domain of the privileged. Exploring large individual-level sources, such as marriage records, death notices, prison and military records, voters' rolls and probate inventories, can bring to light a wealth of new information about the (economic) lives of South Africans that have hitherto remained largely uncharted.

The good news is that the shift towards more cliometric studies in South African history has only just begun. As the attentive reader will notice, most of the studies cited above were published in the last five years. Several research projects now underway at South African and international universities, often in close collaboration, suggest that much more can be expected in the coming years. ${ }^{6}$

But more should be done to attract young black South Africans into the field. There are good (economic) reasons why this will be a slow process. Black economists are sought after in both the private and public sectors, and are woefully underrepresented in Economics departments across South Africa. And because most History departments do not teach quantitative history, young black historians are often not equipped with the statistical skills to benefit from the data revolution. Offering generous bursaries is a good start. So, too, is encouraging students to enrol in international programmes where they can acquire new methods and approaches. The cliometric revolution in South Africa is just taking off. Let us ensure it will be open to all.

\section{References}

Abel, M. 2015. Long-run effects of forced removal under apartheid on social capital. Harvard University Economic History seminar.

Austin, G. \& Broadberry, S. 2014. 'Introduction: The renaissance of African economic history', The Economic History Review, 67(4), 893-906.

Baten, J. \& Fourie, J. 2015. 'Numeracy of Africans, Asians and Europeans during the early modern period: New evidence from Cape Colony court registers', The Economic History Review, 68(2), 632-656.

Boshoff, W.H. \& Fourie, J. 2008. 'Explaining ship traffic fluctuations at the early Cape settlement 1652-1793', South African Journal of Economic History, 23(1-2), 1-27.

\footnotetext{
${ }^{6}$ Two examples are the Andrew W. Mellon Foundation-funded Biography of an Uncharted People project (www.unchartedpeople.org) and the Cape of Good Hope Panel project (www.capepanel.org), a collaborative project between Stellenbosch University and Lund University.
} 
Boshoff, W.H. \& Fourie, J. 2010. 'The significance of the Cape trade route to economic activity in the Cape Colony: A medium-term business cycle analysis', European Review of Economic History, 14(3), 469-503.

Boshoff, W.H. \& Fourie, J. 2017. 'When did South African markets integrate into the global economy?', Studies in Economics and Econometrics, 41(1), 19-32.

Burger, R.P., Burger, R. \& Rossouw, L. 2012. 'The fertility transition in South Africa: A retrospective panel data analysis', Development Southern Africa, 29(5), 738-755.

Cilliers, J. \& Fourie, J. 2018. 'Occupational mobility during South Africa's industrial take-off', South African Journal of Economics, 86(1), 3-22.

Cilliers, J. \& Green, E. 2017. The land-labour hypothesis revised: Wealth, labour and household composition at the South African frontier. African Economic History Network Working Paper Series 2017.34.

Cilliers, J. \& Mariotti, M. 2017. The shaping of a settler fertility transition: Eighteenth and nineteenth century South African demographic history reconsidered. Tech. rep. Centre for Economic History, Research School of Economics, Australian National University.

De Kiewiet, C.W. 1941. A history of South Africa, social and economic. Oxford University Press.

De Kock, M.H. 1924. Selected subjects in the economic history of South Africa. Juta.

Delius, P. \& Schirmer, S. 2014. 'Order, openness, and economic change in precolonial Southern Africa: A perspective from the Bokoni terraces', The Journal of African History 55(1), 37-54.

Du Plessis, S. \& Du Plessis, S. 2012. 'Happy in the service of the company: The purchasing power of VOC salaries at the Cape in the 18th century', Economic History of Developing Regions 27(1), 125-149.

Du Plessis, S \& Fourie, J. 2016. ““'n Droewige laslap op die voos kombers van onreg”: 'n Statistiese analise van konsentrasiekampbewoners', Tydskrif vir Geesteswetenskappe, 56(4-2), $1178-1199$

Du Plessis, S., Jansen, A. \& von Fintel, D. 2015. 'Slave prices and productivity at the Cape of Good Hope from 1700 to 1725: Did everyone win from the trade?', Cliometrica, 9(3), 289-330.

Du Plessis, S. \& Du Plessis, S. 2017. Which comes first: good governance or prosperity? A historical experiment from the South African Republic and the Orange Free State. Tech. rep.

Du Plessis, S. \& Kotzé, K. 2010. 'The great moderation of the South African business cycle', Economic History of Developing Regions, 25(1), 105-125.

Eriksson, K. 2014. 'Does the language of instruction in primary school affect later labour market outcomes? Evidence from South Africa', Economic History of Developing Regions, 29(2), 311335 . 
Fedderke, J. \& Simkins, C. 2012. 'Economic growth in South Africa', Economic History of Developing Regions, 27(1), 176-208.

Fourie, J. 2013a. Slaves as capital investment in the Dutch Cape Colony, 1652-1795. In: Agricultural transformation in global history perspective. Ed. by P. Svensson and E. Hillbom. Routledge, 136-159.

Fourie, J. 2013b. 'The remarkable wealth of the Dutch Cape Colony: Measurements from eighteenth-century probate inventories', The Economic History Review, 66(2), 419-448.

Fourie, J. 2016. 'The data revolution in African economic history', Journal of Interdisciplinary History, 47(2), 193-212.

Fourie, J. \& Von Fintel, D. 2014. 'Settler skills and colonial development: The Huguenot winemakers in eighteenth-century Dutch South Africa', The Economic History Review, 67(4), 932963.

Fourie, J. \& Green, E. 2015. 'The missing people: Accounting for the productivity of indigenous populations in Cape Colonial History', The Journal of African History, 56(2), 195-215.

Fourie, J., Grundlingh, A. \& Mariotti, M. 2017. 'Poor South Africa! Will no nice english people ever come out here? The South African constabulary of the Anglo-Boer war', The Journal of Imperial and Commonwealth History, 45(4), 580-606.

Fourie, J. \& Schirmer, S. 2012. 'The future of South African economic history', Economic History of Developing Regions, 27(1), 114-124.

Fourie, J. \& Swanepoel, C. 2018. “'Impending ruin' or 'remarkable wealth'? The role of private credit markets in the 18th-century Cape Colony', Journal of Southern African Studies, 44(1), 725.

Fourie, J. \& Von Fintel, D. 2010. 'The dynamics of inequality in a newly settled, pre-industrial society: the case of the Cape Colony', Cliometrica, 4(3), 229-267.

Fourie, J. \& Von Fintel, D. 2011. 'A history with evidence: Income inequality in the Dutch Cape colony', Economic History of Developing Regions, 26(1), 16-48.

Giliomee, H. 2009. 'A note on Bantu education, 1953 to 1970', South African Journal of Economics, 77(1), 190-198.

Greif, A. 1997. 'Cliometrics after 40 years', The American Economic Review, 87(2), 400-403.

Greyling, L. \& Verhoef, G. 2015. 'Slow growth, supply shocks and structural change: The GDP of the Cape Colony in the late nineteenth century', Economic History of Developing Regions, 30(1), 23-43.

Gwaindepi, A. 2018. State building in the colonial era: Public revenue, expenditure and borrowing patterns in the Cape Colony, 1820-1910. PhD thesis. Stellenbosch University. 
Hannaford, M.J., Jones, J.M. \& Bigg, G.R. 2015. 'Early nineteenth-century Southern African precipitation reconstructions from ships logbooks', The Holocene, 25(2), 379-390.

Hannaford, M.J. \& Nash, D.J. 2016. 'Climate, history, society over the last millennium in Southeast Africa', Wiley Interdisciplinary Reviews: Climate Change, 7(3), 370-392.

Herranz-Loncá, A. \& Fourie, J. 2018. 'For the public benefit'? Railways in the British Cape Colony', European Review of Economic History, 22, 73-100.

Hopkins, A.G. 2009. 'The new economic history of Africa', The Journal of African History, 50(2), 155-177.

Klein, J., Nash, D., Pribyl, K., Endfield, G.H. \& Hannaford, M. 2018. 'Climate, conflict and society: Changing responses to weather extremes in nineteenth century Zululand', Environment and History.

Magee, G.B., Greyling, L. \& Verhoef, G. 2016. 'South Africa in the Australian mirror: Per capita real GDP in the Cape Colony, Natal, Victoria, and New South Wales, 1861-1909', The Economic History Review, 69(3), 893-914.

Mariotti, M. 2012a. 'Estimating the substitutability of African and white workers in South African manufacturing, 1950-1985', Economic History of Developing Regions, 27(2), 47-60.

Mariotti, M. 2012b. 'Labour markets during apartheid in South Africa', The Economic History Review, 65(3), 1100-1122.

Mariotti, M. 2015. 'Fathers employment and sons' stature: The long-run effects of a positive regional employment shock in South Africa's mining industry', Economic Development and Cultural Change, 63(3), 485-514.

Mariotti, M. \& Fourie, J. 2014. 'The economics of apartheid: An introduction', Economic History of Developing Regions, 29, 113-125.

Mpeta, B., Fourie, J. \& Inwood, K. 2018. 'Black living standards in South Africa before democracy: New evidence from height', South African Journal of Science, 114(1-2), 1-8.

Nash, D.J. \& Endfield, G.H. 2002. 'A 19th century climate chronology for the Kalahari region of central Southern Africa derived from missionary correspondence', International Journal of Climatology, 22(7), 821-841.

Nattrass, N. 2014. 'Deconstructing profitability under apartheid: 1960-1989', Economic History of Developing Regions, 29(2), 245-267.

Nattrass, N. \& Seekings, J. 2011. The economy and poverty in the twentieth century. The Cambridge History of South Africa. Ed. by Mager Anne Ross Robert and Bill Nasson. Cambridge: Cambridge University Press, 1885-1994.

Norling, J. 2018. 'Family planning and fertility in South Africa under apartheid', European Review for Economic History. In press. 
Ramela, O. 2018. The evolution of occupational structures in South Africa 1875-1911: An analysis of the effects of the resource curse and blessing. MA thesis. Stellenbosch University.

Shell, R.C-H. 1994. Children of bondage: A social history of the slave society at the Cape of Good Hope, 1652-1838. Wesleyan University Press published by University Press of New England.

Steckel, R.H. 1995. 'Stature and the standard of living', Journal of economic literature, 33(4), 1903-1940.

Trapido, S. 1990. 'From paternalism to liberalism: The Cape Colony, 1800-1834', The International History Review, 12(1), 76-104.

Van der Berg, S. 2011. 'Current poverty and income distribution in the context of South African history', Economic History of Developing Regions, 26(1), 120-140.

Van Duin, P. \& Ross, R. 1987. The economy of the Cape Colony in the eighteenth century. Centre for the History of European Expansion.

Worden, N. 1985. Slavery in Dutch South Africa. Vol. 44. Cambridge University Press. 